\title{
POSSIBLE FINANCIAL REPORTING CHALLENGES FACED BY GOVERNING BODIES OF PUBLIC SCHOOLS IN SOUTH AFRICA
}

\author{
Moses Thabang Hlongoane \\ Department of Financial Accounting, University of South Africa
}

\begin{abstract}
Some of the South African school governing bodies (SGBs) are faced with various challenges including a lack of skills, corruption and the mismanagement of funds. These challenges make it difficult for the SGBs to discharge their duties. Section 43 of the South African Schools Act (SASA) requires the Members of the Executive Council (MECs) for Education in various provinces to develop financial guidelines for the schools. This results in the use of different accounting and reporting guidelines by governing bodies in various provinces, which may have a negative effect on the comparability and other desirable qualities, such as faithful representation, consistency and understandability of financial information. The research reported here was extracted from a literature review, which forms an integral part of a doctoral study. The study is still in progress and aims to establish the nature of reporting, the effectiveness of existing guidelines and the extent of non-compliance to regulations and existing guidelines by different schools in various provinces in order to develop guidelines to assist SGBs to prepare annual financial statements. The aim of this paper, however, is to discuss possible financial reporting challenges faced by South African SGBs of public schools. This is done by literature review.
\end{abstract}

Keywords: School governing bodies

JEL codes: I22, M41, M48

\section{Introduction and background}

The current South African education system comprises public and independent schools. Public schools include both ordinary and special schools. Public schools are established in terms of section 3 of the South African Schools Act (SASA) (No. 84 of 1996) (Republic of South Africa [RSA], 1996b) and they may receive funds from the state, while independent schools are established in terms of section 5 of the SASA, and may not receive funds from the state (RSA, 1996b). Special schools include all those schools accommodating learners with special needs, such as learners with disabilities. It should be noted that the focus of the paper is on financial reporting by SGBs, and that there is no major difference between the SGBs of both ordinary and special schools. Public schools are required by the SASA to prepare and submit audited financial statements to the district of the Provincial Department of Education.

The SGBs may be facing a number of challenges in playing their roles as governors. Research was previously done with regard to challenges facing the SGBs in the execution of the functions such as financial management (Maile, 2002; Mestry, 2006; Mestry and Naidoo, 2009; Ndou, 2012). However, very little research has been conducted in terms of the challenges facing SGBs in executing their duties with regard to financial reporting. Mestry (2004) found that governing bodies in South Africa are subjected to forensic audits due to mismanagement of funds through misappropriation, fraud, pilfering of cash, theft and improper control of financial records.

The aim of this paper is to discuss possible challenges facing SGBs in respect of financial reporting. Identifying these challenges may lead to solutions being suggested. This may lead to proper financial management and reporting, with possible reduction in financial mismanagement and other fraud-related activities. The study on which this paper reports may contribute as a base for future research in terms of understanding and establishing possible causes of the challenges to 
the SGBs with regard to financial reporting.

In the rest of the paper, the following will be discussed:

- firstly, the researcher gives background of SGBs in South African public schools;

- following that, the researcher will discuss the accountability of SGBs to stakeholders;

- then, the problem statement is stated;

- next, the need for uniform reporting guidelines for SGBs is explained;

- pen ultimately, the schools' financial reporting in terms of the SASA is highlighted followed by an international comparison, and

- lastly, the conclusion will follow.

\section{Background of SGBs in the South African public schools}

Prior to 1994, schools were governed by different school committees, school boards and school councils, which were dominated by the school principals (Ndou, 2012). In 1996, the SASA made provision for the establishment of school governing bodies (SGBs) for public schools. According to sections 23 and 24 of the SASA, the South African SGBs of public schools must be comprised of the principal, selected teachers, non-teaching staff, elected parents as well as learners from Grade 8 or higher. The number of members depends on the number of learners enrolled in the school. If the school is a special school, in addition to the above, there will be representatives from sponsoring bodies, representatives from organisations of disabled persons, disabled persons, as well as experts in relevant fields of special needs education (RSA, 1996b).

Section 23 (6) of the SASA permits the SGB to co-opt members of the public with specific expertise to serve on the governing body. A member co-opted in terms of section 23 (6) does not have voting rights. The SGB shall, from amongst its members, elect office bearers who must include at least a chairperson, a treasurer and a secretary. The chairperson and the treasurer must be parents (RSA, 1996b). Section 30 of the SASA allocates powers to the SGB to establish committees. These committees must include, amongst others, the finance committee, maintenance committee, the Learner Teacher Support Material (LTSM) committee, and the sports committee (RSA, 1996b).

The SASA allocates certain functions to the SGBs. These functions include:

- $\quad$ raising funds for the school (in cash or in kind);

- establishing a school fund and administering it in accordance with directions issued by the Head of Department of basic education;

- opening and maintaining the bank account of the school;

- establishing budget priorities and preparing a budget each year;

- keeping records of funds received and spent by the school and of its assets, liabilities and financial transactions;

- drawing up annual financial statements, not later than three months after the end of each financial year to indicate money received and expenditures incurred by the school during the financial year, as well as its assets and liabilities at the end of the financial year concerned; and

- ensuring that the accounting records and financial statements are audited or examined and submitted to the Head of the Department of Education within six months after the end of each financial year (RSA, 1996a; 1996b).

The SGBs are however, faced with various challenges in performing their duties. These challenges include a lack of financial knowledge and skills, as well as a lack of proper 
understanding of governance (Botha, 2012; Mestry, 2004; Mestry and Naidoo, 2009; Xaba, 2011). Ndou (2012) adds that these challenges may also be a result of inadequate training in governance matters. The SASA, however, puts a huge responsibility on the SGBs with regard to performance of these duties. Mestry and Khumalo (2012) argue that some of the SGBs may have insufficient knowledge and expertise to perform the functions of the schools as allocated by the SASA. They also argue that the provincial departments of education are required by the Schools Act to appropriate money for the training of the SGBs. According to the research conducted by Mestry and Khumalo (2012), some SGBs in their study were concerned that this training was not happening as the provincial departments often claimed not having sufficient resources for this purpose. The need for sufficient training of SGBs, especially on the constitutional principles of governance, was also emphasised by Van Wyk (2004). In addition to these challenges, Bush and Heystek (2003) identify the exclusion of professional management of the schools as one of the challenges. Section 16A (2) of the SASA allocates the professional management of the school to the principal. Section 16A (b) also allocates the responsibility for the effective usage of the resources of the school to the principal. The latter responsibility allocated to the principal might contradict the functions allocated to the SGB in terms of section 20 of the SASA. These functions were discussed in the previous paragraph.

Corruption and financial mismanagement are some of the challenges facing some of the SGBs. In August 2015, Glenvista High School in Gauteng was in the news (The New Age, 2015). This was due to corruption that took place at the school. The former principal, other staff members and the chairperson of the SGB were charged for criminal and civil offences by the Gauteng MEC for Education, Panyaza Lesufi (The New Age, 2015). This followed after a forensic report released by KPMG. The report indicated, amongst others, that the SGB abused section 38A of the SASA by paying more money to certain teachers with rare skills. These payments were not approved by the department. The principal, who was responsible for the appointment of coaches, hired his daughter as one of the coaches at the school without the SGB's approval. The appointment of staff did not follow proper procedures. The school paid for the levies for the personal home of the principal, the building of the carport on the principal's property, personal flight tickets for the principal, and the opening of eight bank accounts instead of one (The New Age, 2015).

In terms of section 37(3) of the SASA, the SGB may only open one bank account. According to this section, the SGB must first get permission from the MEC for Education for the opening of other bank accounts. Xaba (2011) agrees with Ndou (2012) by attributing some of these challenges to a lack of the necessary skills, such as financial management skills, and not being held to account. He also suggests that the three-year term for members to serve on the SGB should be reassessed and increased. In South Africa, the term of the president, ministers and MECs is five years. In England, as discussed in section 7 below, the term of office of school governors is four years (James et al., 2010). It may therefore be recommended to increase the term of office for the SGB as this may give them reasonable time to realise the set objectives. In section 7, below, a comparison between the South African SGBs and SGBs in other countries is made.

\section{Accountability of SGBs to stakeholders}

Toolley and Guthrie (2007) define accountability as the obligation to give an account of one's performance and/or actions. According to Farrell and Law (1999), as well as Doussy and Doussy (2014), accountability is made up of two parts: the "element of account" and "the holding to account". Samkin and Schneider (2007) also describe accountability as "the duty to provide an account or reckoning of actions for which one is held responsible". In South Africa, accountability starts with the national government as provided for in the Constitution of the 
Republic of South Africa (RSA, 1996a). Section 29 of the South African Constitution makes provision for a right to basic and adult education and holds the Department of Basic Education accountable to the parliament in terms of the performance of the country in matters regarding basic education. Section 34 of the SASA makes provision for the state to provide public schools with necessary funding. The school as a public entity is required to comply with sections 55(1) (a)-(b) of the Public Finance Management Act (PFMA) (RSA, 1999). According to this section, the accounting authority for a public entity is required to keep full and proper records of the financial affairs of the public entity, prepare financial statements for each financial year in accordance with generally accepted accounting practice (GAAP), unless the Accounting Standards Board approves the application of generally recognised accounting practice (GRAP) for the public entity. Private sector entities apply GAAP while public sector entities apply GRAP. This means that the schools must also be held accountable for the public funds. Section 21 of the SASA makes provision for various functions and responsibilities of SGBs. These functions include the establishment of a budget, the keeping of records of funds received, and of funds spent, as well as keeping records of the assets, liabilities and financial transactions of the school. The functions also include the establishment and administration of the school fund. Mestry (2006) emphasise that SGBs receive public funds and therefore they are obliged to disclose to stakeholders where the funds came from, what they were intended for, what they will be used for and when and how they will be used. This includes also disclosure of who benefited from the funds.

According to Joubert (2006), SGBs in South Africa have statutory responsibilities for many critical functions within the schools. These responsibilities could make valuable contributions to ensure effective and continued improvements. Mestry $(2004 ; 2006)$ refers to the case of Schoombee and others vs. MEC for Education, Mpumalanga where the judge concluded that the principal could not be accused of financial irregularities as the responsibility for the financial management of the school rests with the governing body. It can therefore be concluded that the SGBs are entrusted with the responsibility to account to the stakeholders.

In private sector, stakeholders include stockholders, creditors, employees, customers, suppliers, public interest groups and government (Jensen, 2001). Coy and Dixon (2004) argue that stakeholders for schools should include feeder schools, suppliers, donors, sponsors, professional associations, unions, alumni, taxpayers, other community members, researchers, media and auditors. The definition of stakeholders by Jensen as well as Coy and Dixon does not include the government as the stakeholder. It is therefore argued that government is one of the stakeholders, especially since the government plays a vital role in the operation of the schools. The stakeholders should be furnished with valuable and sufficient information - such as figures regarding the financial performance of the school (Toolley and Guthrie, 2007) - to enable them to make meaningful decisions. Section 20 of the SASA requires the governing body to present an annual report, which includes financial statements and the budget, at an annual general meeting of parents where the budget must be approved by a majority of parents.

According to Freeman et al. (2011) the financial information should enable decision-makers to -

- compare actual financial results with the adopted budget;

- assess the financial condition and results of operation;

- assist with determining compliance with finance-related laws, rules and regulations; and

- assist in evaluating efficiency and effectiveness.

\section{Problem statement}

Doussy and Doussy (2014) found that South African schools have different guidelines for 
financial reporting and auditing, as opposed to companies.

As supported by Doussy and Doussy, one of the challenges identified is the lack of uniform reporting guidelines for use by SGBs in preparing financial statements. This statement is supported by section 43 of the SASA. According to this section, the MEC for Education of each province is mandated by the SASA to develop their guidelines. This suggests that different provinces may be using different guidelines in preparing financial statements for schools. The use of various guidelines results in the financial reporting of schools being inconsistent, noncomparable and may also affect the reliability and fair representation of financial information.

The question to be answered by this study is: what are challenges faced by the SGBs in preparing the financial reports?

\section{The need for uniform reporting guidelines for SGBs}

Compliance to and use of uniform reporting guidelines make it possible to compare information of the entities operating within the same industry. It is generally known that companies in the private sector use International Financial Reporting Standards (IFRS), while public sector entities should comply with generally recognised accounting practice (GRAP). Guidelines are also used in preparing the financial statements. These financial statements are prepared in order to furnish useful information to different users such as shareholders, creditors, lenders, management, investors, suppliers, competitors, researchers, regulatory bodies and society at large. Such guidelines are designed and prescribed to improve and benchmark the quality of financial reporting with a view to eliminate, to the extent possible, the non-comparability of financial statements and to improve reliability thereof (Kumar and Singh, 2013). The International Accounting Standard 1 (IAS1) refers to enhancing qualitative characteristics of financial statements. One of these enhancing qualitative characteristics is comparability. Users of financial statements need information which is comparable in order to identify trends over time and between similar entities (Koppeschaar et al., 2013).

It is therefore, important that financial information of schools from various provinces should be comparable. The use of uniform guidelines across the country may assist in achieving consistency, comparability and fair representation of financial information and it may also promote the reliability of financial information being reported (Bordoloi and Bordoloi, 2013; Coy, Fisher and Gordon, 2001; Ding, Hope, Jeanjean and Stolowy, 2007; Doussy and Doussy, 2014; Koppeschaar et al., 2013; Yadagiri and Ragender, 2013).

\section{The schools' financial reporting in terms of the SASA}

The SGB of a public school should establish a finance committee which comprises the principal, the chairperson of the SGB, a co-opted member and the SGB treasurer, who must serve as the chairperson of this committee. The treasurer, chairperson and the principal must serve as signatories for the bank account of the school. The finance committee may appoint the finance officer, who will be responsible for the bookkeeping function of the school. The principal, as well as the treasurer, should oversee all the bookkeeping functions of the finance officer. The SASA allocates some duties to the SGBs, which include amongst others, establishment and administration of a school fund for the school. These duties include also the preparation of financial statements, as well as the appointment of an auditor. The accounting records should be submitted to the finance committee on a monthly basis and the financial report must be tabled at the SGB meeting for approval.

As mentioned above, section 42 of the SASA requires the SGB of a public school to keep records 
of funds received and spent, as well as of its assets, liabilities and financial transactions, to prepare and submit audited financial statements to the department of education within six months after the end of the financial period. There is no mention of which components of financial statements are to be prepared, except for section 43 of the SASA, which requires the preparation of financial statements according to the guidelines determined by the provincial MEC for Education. However, keeping of accounting records as well as preparation and presentation of financial statements requires a specialist skill of financial accounting or bookkeeping. This has been mentioned by Xaba (2011) and Mestry (2006) as one of the challenges facing some of the SGBs. Ndou (2012), Rangongo (2011) and Xaba (2011) found that most of the members of SGBs could not interpret the financial reports and that they were not capable of managing the school finances. Rangongo (2011) and Xaba (2011) also emphasised that training may not be sufficient as this also requires specialised expertise. It seems that the department of education should consider hiring skilled people to perform the bookkeeping function at the schools. Then the training may be facilitated to empower the bookkeepers with legislation and policies.

\section{International comparison}

During the last decade of the twentieth century, there has been a major shift to self-governance for schools with the aim of giving them greater powers to manage their affairs within clearly defined national frameworks (Bush and Gamage, 2001; Ngidi, 2004). This shift resulted in changes in the structures of the governing bodies of schools. Governing bodies in countries such as Thailand, England and Wales are comprised of parents, teachers, community representatives, teaching and non-teaching staff, the local authority, partnerships and sponsors, associates as well as the principal (Bush and Heystek, 2003). Bush and Heystek (2003) identify the following five major differences between the education systems in South Africa and England:

- South Africa provides for learner membership of the SGB in secondary schools;

- parents constitute a majority of the governing body in South African SGBs while in England it is not specified (Bush and Gamage, 2001);

- in South Africa, the governing body chair must be a parent representative, while in England it is not specified;

- co-opted members have voting rights in England but not in South Africa; and

- the term of office for school governors in England is four years, as opposed to the threeyear term in South Africa (James et al., 2010).

As compared to South African school governing bodies, governing bodies in England and Wales have the following responsibilities (Farrell and Law, 1999):

- provide a statement of curriculum aims;

- effect any modifications/exemptions to curriculum policies;

- give detailed reports on educational needs, sex education and the arrangements for collective worship at the schools;

- provide a prospectus and an annual report; and

- financial responsibility for decisions relating to school expenditure and for keeping appropriate accounts.

According to the responsibilities listed above, it is clear that school governing bodies of most countries are entrusted with financial responsibilities, which include financial management and reporting for the schools. South Africa has key challenges of unskilled governors, while England faces challenges such as a lack of diversity in the composition of governors, disadvantaged and minority ethnic groups being under-represented and a lack of motivation for lay governors to participate (James et al., 2010). James et al. (2010) mention in their research that the majority of 
members on school boards have education-related occupations, professional or managerial positions, advanced educational degrees or they are professionally qualified.

In the United States of America (Florida), additional financial reporting requirements were introduced to help financially struggling charter schools. The charter schools operate in the same way as public schools in South Africa. The introduction of these requirements was done by strengthening financial auditing and reporting standards (Office of Program Policy Analysis \& Government Accountability, 2008). The election process of the school boards is also different in that in the United States (Virginia), the school boards are elected along political lines (Hess, 2002). Another difference is that the school boards in the United States are remunerated while in South Africa it is regarded as a voluntary duty (Hess, 2002).

\section{Conclusion}

This paper showed how SGBs are accountable to the stakeholders. Accountability starts from the Constitution of the Republic of South Africa, which holds the department of education accountable for the education of the citizens. The department must therefore make resources available to the schools. The SGBs are accordingly also held responsible and should account for the usage of these resources.

Preparation and presentation of accurate, complete and reliable financial statements also lie with the SGBs. The problem statement of the present research outlined the lack of uniform reporting standards or guidelines across the country. This emanates from the fact that various provinces use different reporting guidelines in preparing financial statements, which has a huge effect on consistency, comparability and fair representation of financial statements. This was also raised in the study conducted by Mestry, as well as in the study by Doussy and Doussy (2014).

The envisaged study should answer the following questions:

- What is the extent of inconsistencies in the financial reporting guidelines used by various provinces?

- What is the extent of inconsistencies in the annual financial statements of schools? and

- What is the extent of non-compliance to the regulations and policies in preparing the financial statements?

South African SGBs are faced with various challenges such as corruption and financial mismanagement. Some of the SGBs are unable to implement the finance policies as prescribed by the SASA. These challenges are attributable to, amongst others, lack of financial management and accounting skills; lack of understanding of the Act; lack of monitoring and support by the Department of Education. As mentioned in paragraph 2 above, changes in governance structures as well as the period allocated may also contribute to the inefficiency of these SGBs. This present study identified a lack of uniform reporting guidelines for public schools in South Africa as provinces develop their own guidelines. It was indicated in section 5 above that uniformity in reporting is imperative as it will ensure consistency and comparability of financial information. This will in turn promote the reliability of financial information. It is therefore important for future research to consider the development of uniform guidelines. 


\section{References}

Bordoloi, J., Bordoloi, B. (2013). IFRS: Its relevance, challenges and benefits. In: Bansal, A. Implementation of IFRS an impact on corporate sector in India. Delhi, India: Manglam Publishers \& Distributors, pp. 24-33.

Botha, R. J. (2012). The role of the school principal in the South African school governing body: A case study of various members' perceptions. Journal of Social Science, 30 (3), pp. 263-271.

Bush, T., Gamage, D. (2001). Models of self-governance in schools: Australia and the United Kingdom. The international journal of educational management, 15:1, 39-44.

Bush, T., Heystek, J. (2003). School governance in the new South Africa. Compare: a journal of comparative and international education. 33:2, 127-138, DOI: 10.1080/0305792032000070084.

Coy, D., Fisher, M., Gordon, T. (2001) Public accountability: A new paradigm for college and university annual reports. Critical Perspectives on Accounting, 12, pp. 1-31.

Coy, D., Dixon, K. (2004) The public accountability index: Crafting a parametric disclosure index for annual reports. The British Accounting Review, 36, pp. 79-106.

Ding, Y., Hope, O., Jeanjean, T., Stolowy, H. (2007) Differences between domestic accounting standards and IAS: Measurement, determinants and implications. Journal of Accounting and Public Policy, 26, pp. 1-38.

Doussy, F., Doussy, E. (2014). Financial statements and the discharging of financial accountability of ordinary public schools in South Africa. Journal of governance and regulation, 3 (4), pp. 27-35.

Farrell, M. C., Law, J. (1999). The accountability of school governing bodies. Educational management administration \& leadership. 27:5, DOI: 10.1177/0263211X990271001

Freeman, R. J., Shoulders, C. D., Allison, G. S., Patton, T. K., Smith, G. R. (2011). Government and nonprofit accounting theory and practice, 9th ed. Upper Saddle River, NJ: Pearson.

Hess, F. (2007). School boards at the dawn of the $21^{\text {st }}$ century: Conditions and challenges of district governance. National school boards association. [online] report number 110.

Available at: http://www.nsba.org/bookreports/SBDawn2lstCent [Accessed 24 March 2014].

James, C., Brammer, S., Fertig, M. (2011). International perspectives on school governing under pressure. Educational Management Administration \& Leadership, 39 (4), pp. 394-397.

James, C., Brammer, S., Connolly, M., Fertig, M., James, J., Jones, J. (2010). The hidden givers: A study of governing bodies in England. Education Trust. [online]

Available at:

http://www.cfbt.com/evidenceforeducation/our_research/evidence_for_schools/school_impro vement/the_hidden_givers_a_study_o.aspx [Accessed 24 March 2014].

Jensen, M. (2001). Value maximization, stakeholder theory, and the corporate objective function. Journal of Applied Corporate Finance, 14 (3), pp. 6-21.

Joubert, R. (2006). School governance in South Africa: linking policy and praxis. In: CCEAM Conference 2006: Recreating Linkages between Theory and Praxis in Educational Leadership. [online] Lefkosia, Cyprus: Commonwealth Council for Educational Administration and Management.

Available at:

http://www.topkinisis.com/conference/CCEAM/wib/index/outline/PDF/JOUBERT\%20Rika.p df [Accessed 24 March 2014]. 
Koppeschaar, Z., Sturdy, J., Du Toit, E., Deysel, D., Rossouw, J., Van Wyk, H., Gaie-Booysen, F., Papageorgiou, K., Smith, C., Van der Merwe, C. (2013). Descriptive accounting, 18th ed. Milnerton: Lexis Nexis.

Kumar, A., Singh, I. (2013). India's convergence with International Financial Reporting Standards (IFRS): Implementation of IFRS an impact in corporate sector in India. Bansal, A. Delhi, India. Manglam publishers \& distributors: pp. 34-42.

Maile, S. (2002). Accountability: an essential aspect of school governance. South African journal of education, no. 22 (4), pp. 326-331.

Mestry, R., Khumalo, J. (2012). Governing bodies and learner discipline: Managing rural schools in South Africa through a code of conduct. South African Journal of Education, 32 (1), pp. $97-$ 110 .

Mestry, R., Naidoo, G. (2009). Budget monitoring and control in South African township schools: Democratic governance at risk. Education Management Administration \& Leadership, 37 (1), pp. 107-125.

Mestry, R. (2004). Financial accountability: The principal or the school governing body. South African Journal of Education, 24 (2), pp. 126-132.

Mestry, R. (2006). The functions of school governing bodies in managing school finances. South African Journal of Education, 26 (1), pp. 27-38.

Ndou, N. (2012). Challenges facing school governing bodies in the implementation of finance policies in the Vhembe district. Unpublished masters' dissertation. Pretoria: University of South Africa.

Ngidi, P. (2004). Educators' perceptions of the efficiency of school governing bodies. South African Journal of Education, 24 (4), pp. 260-263.

Office of Program Policy Analysis \& Government Accountability. (2008). Steps taken to improve charter school financial management and performance accountability: additional action needed. [online] Report No. 08-04.

Available at: http://www.oppaga.state.fl.us/reports/pdf/0804rpt.pdf [Accessed 26 Sep. 2016]

Rangongo, P. (2011). The functionality of school governing bodies with regard to the management of finances in public primary schools. Unpublished master's dissertation. Pretoria: University of Pretoria.

Republic of South Africa. (1999). Public Finance Management Act, Act number 1 of 1999. Pretoria: Government Printers.

Republic of South Africa (1996a). The Constitution of the Republic of South Africa, 1996. Pretoria: Government Printer.

Republic of South Africa. (1996b). The South African Schools Act 84 of 1996. Pretoria: Government Printers.

Republic of South Africa. (1996c). The National Education Policy Act: National norms and standards for school funding. Pretoria: Government Printers.

Samkin, G., Schneider A. (2007). Reviewing the changing face of financial reporting: the case of public benefit entity. Working paper series, number 92. New Zealand. The University of Waikato, Department of accounting.

The new age. Gauteng education MEC cracks whip on wrongdoing: crackdown on school. The 
new age, 11 August 2015.

Toolley, S., Guthrie, J. (2007). Reporting performance by New Zealand secondary schools: An analysis of disclosures. Financial Accountability \& Management, 23(4), pp. 351-374.

Van Wyk, N. (2004). School governing bodies: The experiences of South African educators. South African Journal of Education, 24 (1), pp. 49-54.

Xaba, M. I. (2011). The possible cause of school governance challenges in South Africa. South African Journal of Education, 31, pp. 201-211.

Yadagiri, M., Ragender, P. (2013) IFRS and Indian scenario. In: Bansal, A. Implementation of IFRS an impact on corporate sector in India. Delhi, India: Manglam Publishers \& Distributors, pp. 11-23. 